\title{
De la sociologie des techniques à une sociologie des usages
}

L'impossible intégration du magnétoscope dans les réseaux câblés de première génération

Madeleine Akrich

\section{OpenEdition}

Journals

Édition électronique

URL : https://journals.openedition.org/tc/725

DOI : $10.4000 /$ tc. 725

ISSN : 1952-420X

Éditeur

Éditions de l'EHESS

Édition imprimée

Date de publication : 1 novembre 1991

ISSN : 0248-6016

Référence électronique

Madeleine Akrich, «De la sociologie des techniques à une sociologie des usages », Techniques \&

Culture [En ligne], 16 | 1991, mis en ligne le 10 janvier 2006, consulté le 29 septembre 2022. URL :

http://journals.openedition.org/tc/725; DOI : https://doi.org/10.4000/tc.725

Ce document a été généré automatiquement le 29 septembre 2022.

Tous droits réservés 


\section{De la sociologie des techniques à une sociologie des usages}

L'impossible intégration du magnétoscope dans les réseaux câblés de première génération

Madeleine Akrich 